\title{
The Effect of Corporate Governance, Ownership Structure and Firms Characteristics on Financial Performance
}

\author{
Justi Josopandojo $^{1 *} \quad$ Suhadak $^{2} \quad$ Siti Ragil Handayani ${ }^{3} \quad$ Nila Firdausi Nuzula $^{3}$ \\ 1.Doctoral Program of Businness Administration, Brawijaya University Malang \\ 2.Professor - Doctoral Program of Business Administration, Brawijaya University, Malang, Indonesia \\ 3.Lecturer - Doctoral Program of Business Administration, Brawijaya University, Malang, Indonesia
}

\begin{abstract}
This study aims to analyze how theoretically and empirically the factors of Corporate Governance, Ownership Structure and Firm Characteristics have an impact on Financial Performance. Agricultural sector companies listed on the Indonesia Stock Exchange for the period 2014 - 2018 as a research sample. In general, the results of the study indicate that there is a significant and positive influence of Corporate Governance on Financial Performance, which means that the better Corporate Governance will improve Financial Performance. There is no significant effect of Ownership Structure on Financial Performance. There is a significant and negative influence of Firm Characteristic on Financial Performance, this means that the higher Firm Characteristic will decrease Financial Performance.
\end{abstract}

Keywords: Corporate Governance, Ownership Structure, Firm Characteristic, Financial Performnace

DOI: $10.7176 /$ RJFA/11-2-03

Publication date: January $31^{\text {st }} 2020$

\section{Introduction}

Financial Performance dari setiap organisasi memainkan peran penting dalam menjaga kelangsungan dan pertumbuhan perusahaan. Financial Performance ditentukan oleh banyak faktor yang dikenal sebagai faktor keuangan. Beberapa faktor berpengaruh positif dan beberapa faktor berpengaruh negatif terhadap Financial Performance (Das dan Swain, 2017). Dikarenakan faktor-faktor ini memiliki pengaruh yang sangat besar maka perlu diperhatikan faktor-faktor tersebut dalam menyeimbangka pengaruh negatif dan pengaruh positif pada Financial Performance.

Previous researchers have examined several determinants of Financial Performance. Mirza and Javed (2013) state that there is a potential relationship between a company's financial performance and economic indicators, corporate governance, ownership structure, even though the intensity of the relationship is different in different performance measures. Furthermore, Ngwenze and Kariuki, (2017) in their research found that most of the practices of Corporate Governance lead to reduced risks related to debt. A valid model only adequately explains variations in company performance due to changes in Board size, Board composition, board committee independence and the proportion of audit committees. This statement answers the research objectives and confirms that the practices of Corporate Governance practiced by agricultural companies affect their Financial Performance. Ullah et al. (2017) also found evidence of Corporate Governance measured through indicators of non-independent directors, institutional share ownership and the independent board of commissioners positively affecting Financial Performance.

The effect of Corporate Governance on Financial Performance is explained through Agency Theory (Jensen and Meckling, 1976) that agency costs have an important role in the Corporate Governance literature. Agency Theory implies that if there is a fundamental conflict of interest between managers and owners, then Financial Performance will be disrupted. Through the role of good corporate governance, the difference in interests between managers and shareholders can be minimized, so that management is able to focus on doing what the owner expects, namely improving Financial Performance.

Financial performance and survival of a company are largely determined by the quality of the financial strategic decisions made by the company's financial manager. Financial decisions made by financial managers are aimed at achieving company goals. However, in reality these goals are often not implemented due to agency problems, which are caused by the separation of ownership and management functions of the company that can encourage managers to act out of line with company goals.

The effect of Ownership Structure on Financial Performance is explained through Bird In The Hand Theory (Gordon, 1963). Gordon stated that in general investors or majority shareholders avoid risk by choosing dividend payments from shares, rather than potential higher capital gains in the uncertain future. As such, Ownership Structure determines how companies avoid risks and maximize Financial Performance.

Some previous research such as that conducted by Gitundu et al. (2016) found evidence that Ownership Structure has a significant relationship with Financial Performance. Among the individual ownership variables, government ownership has a positive influence on Return on Assets (ROA) and Tobin's Q. Institutional shareholders have a positive influence on ROA and technical efficiency. Large individual investors have a positive 
influence on cost efficiency. Scattered shareholders have a positive influence on ROA but are negative. Furthermore, Lestari and Juliarto (2017) in their research also found evidence that the concentration of ownership has a negative effect on the performance of the company. Managerial ownership was found to have a positive effect with statistical significance on firm performance. Institutional ownership does not have a significant effect on company performance.

Financial Performance reflects measurable results and illustrates the empirical condition of the company within a certain period from various benchmarks with reference to the established standards. Performance appraisal needs to be done to determine the performance achieved, high Financial Performance is a signal to the market. Signal theory explains how signals of success or failure of management (agent) are conveyed to the owner (principal). The Firm Characteristic Relationship to Financial Performance is explained through Signaling Theory (Ross, 1977). According to the theory, Firm Characteristic factors such as the level of growth, the level of business risk or risk, flexibility, and asset availability can provide a positive signal about the company's condition. The signal was captured by shareholders and other stakeholders. This positive signal means that there is public trust in the company. With this trust, the company's Financial Performance can also improve. The high growth of Firm Characteristics gives a signal that shows optimism that the company is capable of high performance.

Some researchers have measured and analyzed the application of Firm Characteristics to Financial Performance as did Abubakar et al. (2018) which states that liquidity and age of the company have a significant negative impact on Financial Performance. Furthermore, Ezechukwu and Amahalu (2017) also find evidence that Firm Characteristics (based on Size) have a positive and significant influence on Financial Performance (Return on Assets, Return on Equity and Return on Capital Employed) at a significant level of 5\%.

This study seeks to develop the results of previous research by developing a more representative model that is by including the variables of Corporate Governance, Structure of ownership, Firm Characteristics of Financial Performance in one test model. The aim is to get a better and comprehensive understanding of the relationship between Corporate Governance, Structure of Ownership, Firm Characteristics of Financial Performance in the framework of developing a body of knowledge and strengthening the explanation of financial theories, primarily the theories of Agency Theory, Bird in the Hand Theory and theory signaling )

Based above the description, this study aims to examine and explain the effect of Corporate Governance, Ownership Structure and Firm Characteristics on Financial Performance in agricultural sub-sector companies listed on the Indonesia Stock Exchange for the period 2014-2018

\section{Theoretical Review and Hypothesis Development 2.1 Corporate Governance}

"Based on The Indonesia Corporate Governance Manual, what is meant by Corporate Governance is a system of relationships that explains the structure and process, the intended relationship is the relationship between shareholders, management and stakeholders. This system of relations involves parties with different interests and even conflicting interests such as the Shareholders, Directors, and / or Board of Commissioners (or other executive bodies). All parties involved in this relationship system have the authority and control of each other over the company. A functioning relationship system will provide benefits and benefits for shareholders. (Suri and Hadad, 2014).

This study uses corporate governance in the form of the Number of the Board of Directors, the Proportion of Independent Commissioners and the Proportion of Independent Audit Committee reflecting or reflecting the implementation of good Corporate Governance (Financial Services Authority regulation Number 33 / POJK.04 / 2014)

\subsection{Ownership Structure}

Jensen \& Meckling (1976) states that Ownership Structure can be used to reduce agency costs stemming from agency problems. Ownership Structure (managerial ownership and institutional ownership) will align management interests with shareholders. Ownership Structure is an important mechanism to control the behavior of managers so that they act very carefully and work more efficiently to increase shareholder wealth. Furthermore Jensen (1986) states that the concentration of ownership through the effort to concentrate ownership of large blocks in a small group of shareholders will have a stronger push to monitor the work of managers. This is due to the argument which states that share ownership by managers is not the only way to unite or align the interests of shareholders with managers.

Measurement of Ownership Structure has been developed by experts, which in essence connects Ownership Structure with the level of corporate control. Cole \& Mehran (1998) suggested that evaluating Ownership Structure can be measured by taking into account (1) the largest percentage of ownership by a director, (2) the largest percentage of ownership by a particular institution or company, and (3) the largest percentage of ownership by non-institution or company certain, and (4) the largest percentage of ownership by company employees. Furthermore Cole \& Mehran (1998) revealed that Ownership Structure, besides being measured by the percentage 
of ownership by the chief executive officer (CEO) or chief director, was also added to the shares owned by the family of the directors.

Jensen \& Meckling (1976) states that Ownership Structure consists of three variables, namely (1) inside equity (held by managers), (2) outside equity (held by anyone outside of the firm), and (3) debt (held by anyone) outside of the firm). Thus the equity is separated between the shareholder from the inside (manager) and the shareholder from outside (someone outside the company). Shareholders of the company can still be seen from how much "share" of the total equity capital. In this study Ownership Structure is measured using Institutional Ownership, Public Ownership and Managerial Ownership (Tarjo, 2008., Wijayanti, 2009 and Sartono, 2010).

\subsection{Firm Characteristic}

Firm Characteristics related to company resources and organizational goals. Companies that have resources and goals can be analyzed using three criteria, namely structure, market and capital related to Firm Characteristics. Firm Characteristic Structure includes, company size, ownership and age. In fact, market-related variables include industry type, uncertainty environment and market environment while capital-related variables consist of liquidity and capital intensity (Kisengo \& Kombo, 2014).

Firm Characteristics in this study were measured using Firm Size Ratio, Profitability Ratio, Liquidity Ratio and Tangibility Asset Ratio (Alipour et al. (2015), Gul et al. (2012), Handoko (2016) and Hossain and Jacob (2014).)

\subsection{Financial Performance}

Financial Performance is a measure of the level of success of a company's management in managing its financial resources, focusing on managing the company's investments in various forms aimed at creating value for shareholders. Gitman (2006) states that Financial Performance is the result of all activities carried out in utilizing financial resources owned. The company's financial performance, in other words is the result of many individual decisions made continuously by management within a company, which can assess the company's performance or overall management.

According to Financial Accounting Standard No. 1 (2002) Financial Performance is the effectiveness of company management in functioning and empowering all elements in the company, which means the higher the company's image in the eyes of outsiders. This Financial Performance Rating involves an analysis of the financial statements. With the analysis of these financial statements can be assessed in the future one way to assess Financial Performance is to use financial ratio analysis

Financial Performance in this study is measured by Return on Assets Ratio, Return on Equity Ratio and Net Profit Margin Ratio (Tachiwou, (2016), Kijewska, (2016), Fatmawati and Suhardjanto, (2018)

\subsection{Hypothesis Development}

\subsubsection{Effect of Corporate Governance on Financial Performance}

The results showed that Corporate Governance (with index variables: Board of Commissioners; Nomination \& Remuneration Committee; and Risk Management Committee) affect Financial Performance, so companies need to apply GCG to improve performance. Most of the practices of Corporate Governance lead to reduced risks related to debt. A valid model only adequately explains variations in company performance due to changes in Board size, Board composition, board committee independence and the proportion of audit committees. This statement answers the research objectives and confirms that corporate governance practices by companies affect their financial performance (Ngwenze and Kariuki, 2017). The influence of corporate governance has a positive impact on financial performance, because good corporate governance will increase investor confidence in financial markets. Good corporate governance creates good intentions, increases the company's financial performance but if the company's governance is poorly managed it will lose the trust of each stakeholder due to suboptimal financial performance (Ullah et al., 2017). Effective Corporate Governance (an effective small board and by an independent board) results in an increase in the company's Financial Performance. Corporate Governance is an ethical investment that may generate long-term financial returns (Dzingai and Fakoya, 2017).

\section{Hypothesis 1: Corporate Governance has a significant effect on Financial Performance}

\subsubsection{Effect of Ownership Structure on Financial Performance}

Ownership Structure has a role in improving company performance and is proven through several studies as follows: that Ownership Structure concentration and Foreign Ownership Structure are positively correlated with Financial Performance of listed companies (Balagobei and Velnampy, 2017). Foreign ownership and government ownership have a positive effect on the company's Financial Performance (Return on Equity) (Fatmawati and Suhardjanto, (2018)). Ownership concentration has a negative effect with statistical significance on company performance. Managerial ownership was found to have a positive effect with statistical significance on firm performance. Institutional ownership does not have a significant effect on company performance, but it is found that institutional ownership has a positive effect on company performance. (Lestari and Juliarto, 2017). 
Hypothesis 2: Ownership Structure has a significant effect on Financial Performance 2.5.3 Effect of Firm Characteristic on Financial Performance

Firm Characteristics (Liquidity and Age) have a negative influence on a company's Financial Performance, and Firm Characteristic (Size) has a positive influence that increases a company's Financial Performance. So companies are advised to convert the majority of their cash and cash equivalents into productive assets that can improve their financial performance. Other research is also encouraged to apply the same variables in various sectors, such as savings banks, oil and gas, transportation, etc. for generalization purposes. (Abubakar et al., 2018). Firm Characteristics (capital adequacy, asset quality, operational efficiency and liquidity) have a positive and significant effect on Financial Performance. Through the credit evaluation process the information asymmetry level will be penetrated and asset quality improved and ultimately will improve Financial Performance. (Ochingo and Muturi, 2018). Firm Characteristic (Size) has a positive and statistically significant effect at the 5\% level on the company's Financial Performance (Return on Assets, Return on Equity and Return on Capital Employed). Firm Characteristics related to capital have a weak positive influence on organizational performance. (Ezechukwu and Amahalu, 2017). Firm Characteristics (growth, size, age, liquidity, and capital structure) have been identified to test their impact on improving the company's Financial Performance (Sinthupundaja and Chiadamrong, 2015).

Hypothesis 3: Firm Characteristic has a significant effect on Financial Performance

\section{Research Methodology}

\subsection{Types and Data Sources}

This type of research is explanatory research with a quantitative approach that aims to "test theories about why and how related traits, behaviors, or events are as they are, or why and how differences are observed between preexisting groups" (O'Dwyer and Bernauer, 2014).

Sources of data in this study are secondary data, which includes data that accumulates on financial statements and periodical data on annual reports of companies, which are listed on the Indonesia Stock Exchange for the period 2014 - 2018 and the Indonesian Capital Market Directory and are relevant to the needs and research objectives..

\subsection{Population and Samples}

The population in this study is part of the data of all business sectors / companies listed on the Indonesia Stock Exchange between 2014 and 2018, which includes: Agricultural Sector, amounting to 22 companies. Samples are subsets of certain group members that are part of the population, which are selected for analysis through sampling techniques that fit the research objectives.

The purposive sampling method is used with the criteria of listed companies and is still active in listing shares on the Indonesia Stock Exchange at least throughout the study period from 2014 to 2018, the company publishes financial statements continuously.

\subsection{Variables and Measurements}

This study uses three Independent variables namely (1) Corporate Governance which is the way how companies are controlled and directed by their stakeholders. (2) Ownership Structure is the distribution of share ownership of a company (3). Firm Characteristics is a characteristic possessed by a company that can distinguish with other companies based on specific aspects namely Firm Size, Profitability, Liquidity Ratio and Tangible Asset Ratio. Dependent Variable is Financial Performance which is a form of achievement achieved by a company in a certain period, describes the extent to which a company has implemented the rules of financial implementation properly and correctly 
Tabel 1. Measurement of Variables

\begin{tabular}{|c|c|c|c|}
\hline No & Variable & Indicator & Measurement \\
\hline \multirow[t]{6}{*}{1} & \multirow{6}{*}{$\begin{array}{l}\text { Corporate } \\
\text { Governance }\end{array}$} & \multirow{2}{*}{ Board of Directors } & Number of Board Directors \\
\hline & & & $\overline{\text { Minimum Niumber of Board directors) }}$ \\
\hline & & \multirow{2}{*}{$\begin{array}{c}\text { Independent } \\
\text { Commissioner }\end{array}$} & Number of Independent Commisioner \\
\hline & & & $\overline{\text { Number of members of the Board of Commissioners }} \times 100 \%$ \\
\hline & & \multirow{2}{*}{ Audit Committee } & Number of committee members \\
\hline & & & $\overline{\text { Jminimum number of committee members }}$ \\
\hline \multirow[t]{6}{*}{2} & \multirow{6}{*}{$\begin{array}{l}\text { Ownership } \\
\text { Structure }\end{array}$} & \multirow{2}{*}{$\begin{array}{l}\text { Institutional } \\
\text { Ownership }\end{array}$} & Number Institutional Shares \\
\hline & & & $\overline{\text { Number of Outstanding Stocks }}$ \\
\hline & & \multirow[t]{2}{*}{ Public Ownership } & Number of Public Shares \\
\hline & & & $\overline{\text { Number of Outstanding Stocks }}$ \\
\hline & & \multirow{2}{*}{$\begin{array}{l}\text { Managerial } \\
\text { Ownership }\end{array}$} & Number of Manajerial Shares \\
\hline & & & $\overline{\text { Number of Outstanding Stocks }}$ \\
\hline \multirow[t]{7}{*}{3} & \multirow{7}{*}{$\begin{array}{l}\text { Firm } \\
\text { Characteristics }\end{array}$} & Firm Size & Natural Logarithm of Total Assets \\
\hline & & \multirow{2}{*}{ Profitability } & Net Income Before Taxes \\
\hline & & & Total Assets (TA) \\
\hline & & \multirow{2}{*}{ Liquidity } & Total Current Assets \\
\hline & & & $\overline{\text { Total Current Liability }}$ \\
\hline & & \multirow{2}{*}{ Tangibility Asset } & Fixed Assets \\
\hline & & & $\overline{\text { Total Assets }}$ \\
\hline \multirow[t]{6}{*}{4} & \multirow{6}{*}{$\begin{array}{l}\text { Financial } \\
\text { Performance }\end{array}$} & \multirow{2}{*}{$\begin{array}{c}\text { Return on Assets } \\
\text { Ratio }\end{array}$} & Net Income \\
\hline & & & $\overline{\text { Total Assets }}$ \\
\hline & & \multirow{2}{*}{$\begin{array}{c}\text { Return on Equity } \\
\text { Ratio }\end{array}$} & Net Income \\
\hline & & & $\overline{\text { Total Equity }}$ \\
\hline & & \multirow{2}{*}{$\begin{array}{l}\text { Net Profit Margin } \\
\text { Ratio }\end{array}$} & Net Income \\
\hline & & & Total Sales \\
\hline
\end{tabular}

\subsection{Data Analysis Method}

Data analysis using the PLS (Partial Least Square) analysis model using WarpPLS (Solimun et al., 2017). The steps of the analysis using WarpPLS are as follows:

1. Designing a Structural Model (inner model). The design of structural models of relationships between latent variables in PLS is based on the formulation of the problem or research hypothesis

2. Designing a Measurement Model (outer model). The outer model in this research is formative, referring to the operational definition of variables

3. Constructing the Path diagram into the form of the inner model and outer model, so that the results are more easily understood, the results of the design of the inner model and the outer model, then expressed in the form of a path diagram.

4. Estimation methods (estimation) parameters using the least squares method (least square methods). The parameter estimation method in the PLS is the structural Equation Model quadratic method with nonparametric in the form of Partial Least Square. The calculation process is done by iteration, where the iteration will stop if a convergent condition has been reached.

5. Model Conformity Test by seeing the degree of concordance between the theoretical model variancecovariance matrix structure and the empirical variance-covariance matrix structure. If the two matrices are identical, then the theoretical model can be concluded perfectly accepted

\section{Results and Analysis}

\subsection{Indicator Exploration Results for Each Variable}

The results of this exploratory analysis in full the value of the factor load and component weights for each variable as in the following table: 
Table 2 . Exploration Results of Indicators for Each Variable in the WarpPLS Model

\begin{tabular}{|c|c|c|c|}
\hline No & Variable /Indicator & Loading/Weight & p-value \\
\hline & \multicolumn{3}{|c|}{ Corporate Governance } \\
\hline 1 & Board of Directors & 0.631 & $<0.001$ \\
\hline 2 & Independent Commissioner & 0.703 & $<0.001$ \\
\hline \multirow[t]{2}{*}{3} & Audit Committee & 0.546 & $<0.001$ \\
\hline & \multicolumn{3}{|c|}{ Ownership Structure } \\
\hline 1 & Institusional Ownership & -0.520 & $<0.001$ \\
\hline 2 & Public Ownership & 0.501 & $<0.001$ \\
\hline \multirow[t]{2}{*}{3} & Manajerial Ownership & 0.128 & 0.112 \\
\hline & \multicolumn{3}{|c|}{ Firm Characteristic } \\
\hline 1 & Firm Size Ratio & 0.216 & $<0.001$ \\
\hline 2 & Profitability Ratio & 0.496 & $<0.001$ \\
\hline 3 & Liquidity Ratio & 0.527 & $<0.001$ \\
\hline \multirow[t]{2}{*}{4} & Tangibility Asset Ratio & -0.382 & $<0.001$ \\
\hline & \multicolumn{3}{|c|}{ Financial Performance (Y2) } \\
\hline 1 & Return on Assets Ratio & 0.515 & $<0.001$ \\
\hline 2 & Return on Equity Ratio & 0.059 & 0.291 \\
\hline 3 & Net Profit Margin Ratio & 0.512 & $<0.001$ \\
\hline
\end{tabular}

Based on the results of the analysis in Table 2, it can be seen that the Ownership Structure variable, which is the Managerial Ownership indicator, has a p-value that is not significant, and the Financial Performance variable on the Return on Equity Ratio indicator is not significant. Thus, there are 2 indicators that are excluded from the model.

\subsection{Model fit and quality indices model WarpPLS}

In the WarpPLS analysis there is a fit model size and quality index, as in the following table Tabel 3. Model fit and quality indices model WarpPLS

\begin{tabular}{|c|c|c|c|c|}
\hline No & Model Fit and Quality Indices & Fit Criteria & Value & Result \\
\hline 1 & Average path coefficient (APC) & $\mathrm{P}<0.05$ & $\begin{array}{c}0.304 \\
\mathrm{P}<0.001\end{array}$ & Good \\
\hline 2 & Average R-squared (ARS) & $\mathrm{P}<0.05$ & $\begin{array}{c}0.446 \\
\mathrm{P}<0.001\end{array}$ & Good \\
\hline 3 & Average adjusted R-squared (AARS) & $\mathrm{P}<0.05$ & $\begin{array}{c}0.424 \\
\mathrm{P}<0.001\end{array}$ & Good \\
\hline 4 & Average block VIF (AVIF) & $\begin{array}{c}\text { acceptable if }<5, \\
\text { ideally }<3.3\end{array}$ & 1.131 & Ideal \\
\hline 5 & Average full collinearity VIF (AFVIF) & $\begin{array}{c}\text { acceptable if }<5, \\
\text { ideally }<3.3\end{array}$ & 1.413 & Ideal \\
\hline 6 & Tenenhaus GoF (GoF) & $\begin{array}{c}\text { small }>0.1, \\
\text { large }>0.36\end{array}$ & 0.553 & Large \\
\hline 7 & Sympson's paradox ratio (SPR) & $\begin{array}{c}\text { acceptable if }>0.7, \\
\text { ideally 1 }\end{array}$ & 0.714 & Good \\
\hline 8 & R-squared contribution ratio (RSCR) & $\begin{array}{c}\text { acceptable if }>0.9, \\
\text { ideally 1 }\end{array}$ & 0.946 & Good \\
\hline 9 & Statistical suppression ratio (SSR) & acceptable if $>0.7$ & 0.714 & Good \\
\hline 10 & Nonlinear bivariate causality direction ratio (NLBCDR) & acceptable if $>0.7$ & 0.946 & Good \\
\hline
\end{tabular}

Table 3 shows that the model is fit, that is, all the fit and quality indices models are fulfilled. Thus the model is said to be good and can be used to explain the phenomena (systems) that are studied and can be used for hypothesis testing

\subsection{Hypothesis Testing Results}

Tabel 4. Hypothesis Testing Results

\begin{tabular}{|c|c|c|c|c|}
\hline Hypothesis & Relationship between Variables & Koefisien & P-value & explanation \\
\hline 1 & Corporate Governance $\rightarrow$ Financial Performance & $0.087 * * *$ & 0.010 & Significant \\
\hline 2 & Ownership Structure $\rightarrow$ Financial Performance & $-0.091 \mathrm{~ns}$ & 0.138 & Non Significant \\
\hline 3 & Firm Characteristic $\rightarrow$ Financial Performance & $-0.205^{* * *}$ & 0.006 & Significant \\
\hline
\end{tabular}


Based on Table 4, the results of hypothesis testing are as follows:

The influence of Corporate Governance on Financial Performance obtained a path coefficient of 0.087 and $\mathrm{P}$-value $=0.010$. Because the $\mathrm{P}$-value $<0.05$, and the coefficient marked positive indicates that there is a significant and positive influence of Corporate Governance on Financial Performance. This means that the higher the Corporate Governance, the higher the Financial Performance will be. Thus, hypothesis 1 of this study was accepted. Effect of Ownership Structure on Financial Performance obtained a path coefficient of -0.091 and P-value $=0.138$. Because the P-value $>0.05$, and the coefficient marked negative indicates that there is no significant effect of Ownership Structure on Financial Performance. Thus, hypothesis 2 of this study was rejected.

Effect of Firm Characteristics on Financial Performance obtained a path coefficient of -0.205 and P-value $=$ 0.006. Because the P-value $<0.05$, and the coefficient marked negative indicates that there is a significant and negative influence. Firm Characteristics of Financial Performance. This means that the higher Firm Characteristic will result in lower Financial Performance. Thus, hypothesis 3 of this study was accepted.

\section{Discussion}

\subsection{Effect of Corporate Governance on Financial Performance}

Hypothesis 1 of this study was accepted, because of the influence of Corporate Governance on Financial Performance, a path coefficient of 0.087 and P-value $=0.010$ were obtained. Because the P-value $<0.05$, and the coefficient marked positive indicates that there is a significant and positive influence of Corporate Governance on Financial Performance This means that the stronger the Corporate Governance, the significant positive impact on Financial Performance.

The results of this study are supported by several studies, among others: Dzingai and Fakoya (2017) which states that effective corporate governance despite using the size of a small number of board members and monitoring by independent board members, still results in an increase in the company's financial performance. Furthermore Tachiwou (2016) states the implementation of Corporate Governance and its relationship with company performance, showing a positive and significant relationship between Governance and Financial Performance. Ullah et al. (2017) in his research on the influence of Corporate Governance on Financial Performance. Showing that Corporate Governance has a positive impact on Financial Performance.

Positive and significant improvement shows a strong impact between Corporate Governance and Financial Performance. Thus, the stronger or weaker Corporate Governance will directly affect performance. The results indicate that Financial Performance in agribusiness companies in Indonesia refers to Agency Theory. This means that the financial performance of agribusiness companies in Indonesia is formed on the basis of a mutual agreement between the owner and management through good corporate governance. Strong or weak corporate governance will significantly influence the achievement of the company's financial performance

\subsection{Effect of Ownership Structure on Financial Performance}

Hypothesis 2 of this study was rejected, because the effect of Ownership Structure on Financial Performance obtained a path coefficient of -0.091 and P-value $=0.138$. Because the P-value $>0.05$, and the coefficient marked negative indicates that there is no significant effect of Ownership Structure on Financial Performance.

The results of this study contradict the research of Lestari and Juliarto (2017) which shows that concentrated ownership has a negative effect on statistical significance on company performance. Managerial ownership was found to have a positive effect with statistical significance on firm performance. Institutional ownership does not have a significant effect on company performance, but it is found that institutional ownership has a positive effect on company performance according to this study. These findings contradict the research of Gugong et al. (2014) states that there is a significant positive relationship between Ownership Structure and company performance as measured by ROA and ROE .; Gitundu et al. (2016) states: Government ownership has a positive effect on Return on Assets and Tobin-Q; and negative effects on cost efficiency; Institutional ownership has a positive effect on Return on Assets and technical efficiency. Majority ownership has a positive effect on cost efficiency. Spread Ownership has a positive effect on Return on Assets and a negative effect on cost efficiency.

The insignificant influence between Ownership Structure and Financial Performance in this study indicates that the empirical Ownership Structure has nothing to do in improving Financial Performance in agribusiness companies on the Indonesia Stock Exchange. The results of the study indicate that Financial Performance in agribusiness companies in Indonesia is determined in Bird In The Hand Theory. This means that there is an effort to avoid risk, in which the investor / majority shareholder chooses dividend payments on shares, rather than potential higher capital gains in the future but is uncertain. This means that the higher ownership structure does not significantly influence the company's financial performance.

\subsection{Effect of Firm Characteristic on Financial Performance}

Hypothesis 3 of this study was accepted, because of the influence of Firm Characteristics on Financial Performance, a path coefficient of $-0,205$ and $\mathrm{P}$-value $=0.006$ were obtained. Because the P-value $<0.05$, and the coefficient 
marked negative indicates that there is a significant and negative influence. Firm Characteristics of Financial Performance. This means that the higher Firm Characteristic will result in lower Financial Performance.

The results of this study are supported by the research of Abubakar et al. (2018) which states that Firm Characteristics as measured by the level of liquidity and age of the company have a negative and significant impact on the company's Financial Performance, meaning that an increase in the ratio of current assets will reduce the company's Financial Performance. It is recommended that most of their cash and cash equivalents are converted into productive assets so that the company's Financial Performance can be improved.

These findings contradict Ochingo and Muturi's research (2018) that Firm Characteristics with indicators of capital adequacy, asset quality, operational efficiency and liquidity have a positive and significant effect on Financial Performance; and Ezechukwu and Amahalu's research (2017) that Firm Characteristics has a statistically significant positive effect on Financial Performance as measured by Return on Asset, Return on Equity and Return on Capital Employed indicators at significant levels.

The negative relationship between Firm Characteristics with Financial Performance in this study indicates that the Firm Characteristic empirically cannot always be used to improve Financial Performance in agribusiness companies on the Indonesia Stock Exchange

The results indicate that Financial Performance in agribusiness companies in Indonesia refers to Signaling Theory. This means that there is a positive signal from Firm Characteristic that affects the company's optimism to achieve its financial performance. High or low Firm Characteristic will significantly influence the impact of high or low Financial Performance. The high growth of Firm Characteristic indicators gives signals that can reduce Financial Performance.

\section{Conclusion}

Corporate Governance as measured by the Number of the Board of Directors, the Proportion of Independent Commissioners and the Proportion of Independent Audit Committee has a significant influence with a positive direction on Financial Performance. The findings are in accordance with the opinion of Jensen \& Meckling (1976) that Corporate Governance will positively influence Financial Performance due to agency control. Corporate governance is a guideline and control mechanism for managers to manage the company in best practice

Ownership Structure has no significant effect on Financial Performance, this means that there is still a concentration of company ownership in the Agricultural Sector companies in Indonesia which are the research sample. The concentration of company ownership in Ownership Structure in companies in the agricultural sector in Indonesia is the sample of this study. This finding also indicates that the management of the company is still under control or is an extension of the majority shareholder, that is, by a corporate legal entity or a holding company that is controlled by certain families only through institutional ownership, so that company management will prioritize the interests of the majority shareholder by the entity legal company or holding company and family through institutional ownership compared to the interests of all shareholders

Firm Characteristic has a significant negative effect on Financial Performance, this shows the presence of characteristic indicators that form the opposite direction (negative) with the conclusion (3) because in this study Firm Characteristic - Liquidity is very significant as a determinant of the variable characteristics of Financial Performance - Return on Assets. Increased Firm Characteristics - Liquidity shows an increase in current assets that will cause a decrease in Financial Performance - Return on Assets, due to reduced income.

\section{References}

Abubakar, Abubakar; Sulaiman, Isah; and Haruna, Usman; (2018), Effect of Firms Characteristics on Financial Performance of Listed Insurance Companies in Nigeria, African Journal of History and Archaeology, 3 (1), $75-82$

Alipour, Mohammad; Mohammadi, Mir Farhad Seddigh; Derakhshan, Hojjatollah; (2015), Determinants of capital structure: an empirical study of firms in Iran, International Journal of Law and Management,. 57 (1), 53-83

Balagobei, Saseela and Velnampy, Thirunavukkarasu (2017), Performance of Listed Beverage Food and Tobacco Companies in Sri Lanka, International Journal of Accounting and Financial Reporting ISSN 2162-3082 2017, 7 (2)

Cole, Rebel. A \& Hamid, Mehran. (1998). The Effect of change in ownership Structure on Performnace: Evidence from Thirt Indutry. Journal of Financial Economics. 50, 291-517

Das, Chandrika Prasad and Swain, Rabindra Kumar (2017), Impact of Organizational Factors on Financial Performance, Parikalpana - KIIT Journal of Management (December 2017)

Dzingai, Isaih and Fakoya, Michael Bamidele; (2017), Effect of Corporate Governance Structure on the Financial Performance of Johannesburg Stock Exchange (JSE)-Listed Mining Firms, Sustainability, 9( 867), 1-15

Ezechukwu Beatrice 0. and Amahalu, Ndubuisi Nestor (2017), Effect of Firm Characteristics on Financial Performance of Quoted Deposit Money Banks in Nigeria, Published By: COA Heritage Nig. Ltd

Fatmawati, Rini and Suhardjanto, Djoko, (2018), Corporate Governance and Its Influence on Financial 
Performance of State-Owned Enterprises (Soes) In Indonesia, International Journal of Business and Management Invention (IJBMI) 7(2), 63-73

Gitundu, Esther Wanjugu; Kiprop, Symon Kibet; Kibet, Lawrence Kangogo; Kisaka, Sifunjo E.; (2016), The influence of ownership structure on financial performance of privatized companies in Kenya, African Journal of Business Management, 10(4), 75-88.

Gitman, L. J. (2006). Principles of Managerial Finance, International Edition (Vol. 10th editi). Boston: Pearson Education

Gordon, Myron J. (1963). Optimal Investment and Financing Policy. .Journal of Finance. 18 (2) 264-272.

Gugong et al. (2014) Gugong, Benjamin Kumai; Arugu, Love O; Dandago, Kabiru Isa; (2014), The Impact of Ownership Structure on the Financial Performance of Listed Insurance Firms in Nigeria, International Journal of Academic Research in Accounting, Finance and Management Sciences 4 (1), 409-416

Gul, Sajid; Muhammad Bilal Khan; Razzaq, Nasir; and Saif, Naveed. (2012). "How Firm Characteristics Affect Capital Structure in Banking and Insurance Sectors (The Case of Pakistan)". European Journal of Business and Management, 4 (12), 6-15

Handoko, Didy; (2016), The Influence of Firm Characteristics on Capital Structure and Firm Value: An Empirical Study of Indonesia Insurance Companies, International Journal of Economics, Commerce and Management United Kingdom, IV (4),1181-1206

Hossain, Md. Musharof and Yakub, K. M. (2014), Impact of firm characteristics on Capital Structure of Banking Industry of Bangladesh, IOSR Journal of Business and Management, 16 (4)., 17-25

Jensen, M., \& Meckling, W. (1976). Theory of the Firm: Managerial Behaviour, Agency Costs, and Ownership Structure. Journal of Financial Economics, 305-360

Jensen, M.C. (1986). Agency Cost of Free Cash Flow, Corporate Finance and Takeover. American Economic Review..76, 323-329

Kijewska, A, (2016), Determinants of The Return on Equity Ratio (ROE) on The Example of Companies from Metallurgy and Mining Sector in Poland, Metalurgija 2, 285-288

Kisengo, Z. M., \& Kombo, H. (2014). Effect of Firm Characteristics on Performance of the Microfinance Sector in Nakuru, Kenya. International Journal of Science and Research (IJSR), 3(10), 1791-1799

Lestari, Nopi Puji dan Juliarto, Agung; (2017); Pengaruh Dimensi Struktur Kepemilikan Terhadap Kinerja Perusahaan Manufaktur; DIPONEGORO JOURNAL OF ACCOUNTING, 6 (3), 1-10 http://ejournals1.undip.ac.id/index.php/accounting ISSN (Online): 2337-3806

Mirza, Sidra Ali and Javed, Attiya (2013), Determinants of financial performance of a firm: Case of Pakistani stock market, Journal of Economics and International Finance, 5(2), 43-52

Ngwenze, Miriam K. and Kariuki, Morris Irungu; (2017), Effect of Corporate Governance Practices on Financial Performance of Listed Agricultural Firms in The Nairobi Securities Exchange, Kenya, IOSR Journal of Economics and Finance (IOSR-JEF), 8 (3), 106-115

O’Dwyer, L. M., \& Bernauer, J. A. (2014). Quantitative research for the qualitative researcher. Thousand Oaks, CA: SAGE Ochingo and Muturi, 2018

Ross, S. A. (1977). The Determination of Financial Structure: The Incentive Signalling Approach. Bell Journal of Economics, 8(1), 23-40. Retrieved from http://www.jstor.org/stable/3003485

Sartono, R. Agus. 2010. Manajemen Keuangan (Teori Dan Aplikasi). Edisi Keempat. Yogyakarta: BPFE.

Sinthupundaja, Janthorn and Chiadamrong, Navee (2015), Investigation of Thai Manufacturing Public Firms' Characteristics and Financial Strategies towards Financial Performance's Improvement, Journal of Economics, Business and Management, 3 (3), 1-15

Solimun, Fernandes, A.A.E., dan Nurjannah (2017), Metode Statistika Multivariat Pemodelan Persamaan Struktural (SEM) Pendekatan WarpPLS. Malang: UB Press

Suri, Sarves and Hadad, Muliaman. D. 2014. The Indonesia Corporate Governance Manual. First Edition. Indoensia Financial Service Authority.

Tachiwou, Aboudou Maman; (2016), Corporate Governance and Firms'Financial Performance of Listed Company in the West African Monetary Union (Wamu) Regional Financial Exchange, International Journal of Economics and Finance; 8 (8)

Tarjo. 2008. Pengaruh Konsentrasi Kepemilikan Institusional dan Leverage Terhadap Manajemen Laba, Nilai Pemegang saham serta Cost of Equity Capital. Simposium Nasioanal Akuntansi XI. Pontianak

Ullah (Atta), Kashif, Muhammad, Saif, Ullah; (2017), Impact of Capital Structure on Financial Performance of Textile Sector in Pakistan, KASBIT Business Journal (KBJ). 10, 1-20

Wijayanti, Ngestiana. 2009. Penagruh Profitabilitas, Umur Perusahaan, Ukuran Perusahaan dan Kepemilikan Publik terhadap Ketepatan waktu pelaporan keuangan. Surakarta: Universitas Sebelas Maret. 